\section{Homenagem a Maria Lúcia Carvalho da Silva: assistente social, docente e amiga querida}

Tribute to Maria Lucia Carvalho da Silva: social worker, teacher and dear friend

\section{Ademir Alves da Silva}

Programa de Estudos Pós-Graduados em Serviço Social da PUC-SP, Brasil.

adecris@uol.com.br

\section{Maria Carmelita Yazbek}

Programa de Estudos Pós-Graduados em Serviço Social da PUC-SP, Brasil. mcyaz@uol.com.br

\section{Mariangela Belfiore Wanderley}

Programa de Estudos Pós-Graduados em Serviço Social da PUC-SP, Brasil.

marilew@uol.com.br

\section{Rosangela Dias Oliveira da Paz \\ Programa de Estudos Pós-Graduados em Serviço Social da PUC-SP, Brasil.}

rosapaz@uol.com.br

Uma vida plena! É o que podemos dizer de Malu, como a tratávamos carinhosamente.

Ela mesma se definia como uma assistente social que pertencia à segunda geração de assistentes sociais brasileiras, formada entre os anos 1950 e 1965 do século XX pela Escola de Serviço Social de São Paulo, herdeira direta das chamadas pioneiras. Não perdia a oportunidade de declarar que tinha feito a melhor escolha profissional e que se orgulhava de ser assistente social! A trajetória profissional da Profa. Malu identifica-se com a história do Serviço Social brasileiro e latino-americano.

Malu acompanhou o movimento de construção do Serviço Social brasileiro em fértil convivência com as gerações que a seguiram, deixando uma imensa contribuição para o Desenvolvimento de Comunidade no Brasil e em outros países, uma experiência rica na construção do Serviço Social do Estado de São Paulo, o primeiro órgão público brasileiro de Serviço Social, além de sua contribuição ao Movimento de Reconceituação e de sua capacidade como educadora, de seu delicado poder de trabalhar com os alunos e conseguir com eles chegar ao essencial de seus trabalhos.

Em 1960 ingressou, por concurso público, no então Serviço Social do Estado de São Paulo, onde se encaminhou para o Desenvolvimento de Comunidade - DC, com uma equipe de quatro assistentes sociais, sob a supervisão da Profa. Helena Iracy Junqueira. Aí desenvolveu uma experiência de seis anos, construindo novas práticas de trabalho social com comunidades. Dirigiu a primeira unidade administrativa de DC no Governo do Estado de São Paulo.

Com o estímulo de Helena Iracy Junqueira, iniciou em 1963 sua trajetória como docente na Escola de Serviço Social e começou a escrever e analisar experiências de DC fora 
de São Paulo, promovidas pela SUDENE, pelo INCRA e pelo MEB. Assim, passou a conjugar o exercício profissional com a docência e com a participação nos principais eventos promovidos pelas entidades representativas do Serviço Social brasileiro (ABESS, CEFAS, CBCISS).

Seus estudos permitiram-lhe o contato com intelectuais privilegiados como Celso Furtado, Florestan Fernandes, Luis Pereira, Paulo Freire e Simone de Beauvoir. O clima era de mudanças e de participação popular em busca de reformas de base. Emergiam novas manifestações na música popular, no cinema novo e na luta pela emancipação feminina.

No entanto, o golpe militar de 1964 e a instauração da ditadura trazem consequências cerceadoras para esse contexto e também para o Serviço Social e para o DC. Foi quando, na busca da resistência, foi convidada para apresentar uma Conferência no Seminário Regional sobre o Serviço Social em face das mudanças na América Latina em Porto Alegre, em 1965. A conferência foi: "A responsabilidade do Assistente Social no Desenvolvimento da América Latina”. Esse evento foi considerado o início do processo de Reconceituação do Serviço Social latino-americano. Malu, juntamente com Seno Cornely, Herman Kruse, Natalio Kisnerman e outros, viria a ser parte da chamada "Geração 65", que buscou inserir o Serviço Social no contexto de mudanças que vivia a América Latina.

Uma experiência relevante na trajetória de Malu foi a de bolsista da ONU, que lhe permitiu conhecer e estudar programas de DC no Chile, Filipinas, Tailândia, Bangladesh, Índia e Paquistão, o que enriqueceu e ampliou os olhares e as perspectivas para a profissão do Serviço Social.

Malu dedicou a maior parte de sua vida à docência. Por mais de 35 anos dedicou-se à orientação de dissertações de mestrado e teses de doutorado no Programa de Estudos Pós-Graduados em Serviço Social. Sempre disponível para compor grupos de trabalho e responder às demandas acadêmicas, Malu tinha impressionante capacidade de contribuir para agregar e fortalecer as equipes em face das demandas do cotidiano acadêmico.

Malu foi responsável pela criação, junto com a Profa. Nobuco Kameyama, do Núcleo de Estudos e Pesquisas sobre Movimentos Sociais - NEMOS, do Programa de Estudos Pós-Graduados em Serviço Social da PUC-SP, tendo sido sua coordenadora por mais de 20 anos, um espaço interdisciplinar de estudos teóricos e pesquisas referentes a movimentos sociais, sujeitos coletivos e à conjuntura política e econômica nacional e internacional, além de articulação e intercâmbio com núcleos similares e outras entidades de pesquisa e assessoria. Ouvir, receber e estar junto com movimentos sociais era para ela um momento especial da vida acadêmica. Foram muitos convites e debates com lideranças de movimentos de moradia, sem-terra, mulheres, negros, além de participar ativamente de várias edições do Fórum Social Mundial em Porto Alegre. 
Sua atuação acadêmica foi pautada pelo rigor metodológico, pelo espírito investigador, pela competência, compromisso, respeito, autonomia e coerência intelectual.

Participou também na gestão do Instituto Brasileiro de Estudos e Ação Comunitária (IBEAC), do qual foi presidente no período de 2007 a 2013. Foi membro do Conselho Editorial da área de Serviço Social da Cortez Editora desde o ano 2000 e de conselhos editoriais de várias outras revistas da área.

Malu foi movida por afetos e provocações teóricas, e assim nos impulsionou a continuar em movimento. Partiu no dia $1^{\circ}$ de julho de 2016, deixando imensa saudade em seus alunos, colegas e amigos.

Dela, fica a lembrança da generosidade, respeito e carinho com que acolhia a todos, da sua energia e competência na defesa de suas posições ético-políticas. Uma pessoa linda, leve, especial, encantadora.

Como diria Guimarães Rosa, "as pessoas não morrem, ficam encantadas".

Recebido em 14/7/2016

Aprovado em 15/7/2016 